\title{
Rheinheimera nanhaiensis sp. nov., isolated from marine sediments, and emended description of the genus Rheinheimera Brettar et al. 2002 emend. Merchant et al. 2007
}

Correspondence Yu-Zhong Zhang zhangyz@sdu.edu.cn

\author{
Hui-Juan Li, ${ }^{1,2} \dagger$ Xi-Ying Zhang, ${ }^{1} \dagger$ Yan-Jiao Zhang, ${ }^{1}$ Ming-Yang Zhou, ${ }^{1}$ \\ Zhao-Ming Gao, ${ }^{1}$ Xiu-Lan Chen, ${ }^{1}$ Hong-Yue Dang ${ }^{3}$ and Yu-Zhong Zhang ${ }^{1}$ \\ ${ }^{1}$ The State Key Laboratory of Microbial Technology, Marine Biotechnology Research Center, \\ Shandong University, Jinan 250100, PR China \\ ${ }^{2}$ College of Chemical and Environmental Engineering, Shandong University of Science and \\ Technology, Qingdao 266510, PR China \\ ${ }^{3}$ Centre for Bioengineering and Biotechnology, China University of Petroleum (East China), \\ Qingdao 266555, PR China
}

\begin{abstract}
A Gram-negative, facultatively aerobic, oxidase- and catalase-positive, rod-shaped bacterium, designated strain E407-8 ${ }^{\top}$, was isolated from a sediment sample from the South China Sea. Phylogenetic analysis of the $16 \mathrm{~S}$ rRNA gene sequence revealed that strain $\mathrm{E} 407-8^{\top}$ was affiliated with the genus Rheinheimera, sharing the highest sequence similarity with Rheinheimera pacifica KMM $1406^{\top}(97.5 \%)$ and Rheinheimera aquimaris SW-353 ${ }^{\top}(97.4 \%)$ and showing less than $97 \%$ sequence similarity to the type strains of other recognized Rheinheimera species. Levels of DNA-DNA relatedness of strain $\mathrm{E} 407-8^{\top}$ to $R$. pacifica DSM $17616^{\top}$ and $R$. aquimaris JCM $14331^{\top}$ were $25.2 \%(25.3 \%$ in the duplicate measurement) and $9.4 \%(6.5 \%)$, respectively. The bacterium could grow at $10-48{ }^{\circ} \mathrm{C}$ (optimum $37{ }^{\circ} \mathrm{C}$ ) and in the presence of $0-8 \%(\mathrm{w} / \mathrm{v}) \mathrm{NaCl}$ (optimum $0.5-2.5 \%$ ). The major cellular fatty acids of strain E407-8 ${ }^{\top}$ were summed feature 3 $\left(\mathrm{C}_{16: 1} \omega 7 c\right.$ and/or iso- $\left.\mathrm{C}_{15: 0} 2-\mathrm{OH}\right), \mathrm{C}_{17: 1} \omega 8 c, \mathrm{C}_{16: 0}$ and $\mathrm{C}_{18: 1} \omega 7 \mathrm{c}$. The predominant respiratory quinone was ubiquinone $\mathrm{Q}-8$. The DNA G $+\mathrm{C}$ content was $51.0 \mathrm{~mol} \%$. Based on the results of our polyphasic taxonomic study, strain $E 407-8^{\top}$ represents a novel species in the genus Rheinheimera, for which the name Rheinheimera nanhaiensis sp. nov. is proposed. The type strain is $E 407-8^{\top}\left(=\right.$ CCTCC AB $209089^{\top}=$ KACC $\left.14030^{\top}\right)$. An emended description of the genus Rheinheimera Brettar et al. 2002 emend. Merchant et al. 2007 is also proposed.
\end{abstract}

The genus Rheinheimera, belonging to the family Chromatiaceae in the class Gammaproteobacteria, was originally proposed by Brettar et al. (2002) for a small group of closely related Gram-negative, flagellated, blue-coloured bacterial strains isolated from seawater samples from different depths of the central Baltic Sea. At the time of writing, the genus Rheinheimera contains eight recognized species, Rheinheimera baltica (the type species; Brettar et al., 2002), R. pacifica (Romanenko et al., 2003), R. perlucida (Brettar et al., 2006), R. aquimaris (Yoon et al., 2007), R. chironomi (Halpern et al., 2007), R. texasensis (Merchant et al., 2007), R. soli (Ryu et al., 2008) and $R$.

†These authors contributed equally to this work.

The GenBank/EMBL/DDBJ accession number for the 16S rRNA gene sequence of strain E407-8 ${ }^{\top}$ is FJ169968.

A supplementary figure is available with the online version of this paper. tangshanensis (Zhang et al., 2008). Most Rheinheimera species have originated from aquatic (marine or freshwater) environments, with the exceptions of $R$. soli from a playground soil sample and $R$. tangshanensis from riceplant root samples, indicating that members of this genus may be widespread in various environments (Ryu et al., 2008; Zhang et al., 2008).

In our recent study on the diversity of protease-producing marine bacteria (Zhou et al., 2009), a protease-producing Rheinheimera-like strain, designated $\mathrm{E} 407-8^{\mathrm{T}}$, was isolated from a deep-sea sediment sample from the South China Sea. In this paper, based on a polyphasic taxonomic study, strain $\mathrm{E} 407-8^{\mathrm{T}}$ is proposed to represent a novel Rheinheimera species.

A marine sediment sample was collected from station E407 $\left(18^{\circ} 29.810^{\prime} \mathrm{N} 112^{\circ} 0.017^{\prime} \mathrm{E}\right)$ at a water depth of $1800 \mathrm{~m}$ using a core sampler, during the South China Sea Open 
Cruise of R/V Shiyan 3 in August 2007. Strain E407-8 ${ }^{\mathrm{T}}$ was isolated from the sediment sample using the dilution plating technique on a screening medium containing $0.2 \%$ yeast extract (Oxoid), $0.3 \%$ casein, $0.5 \%$ gelatin, $1.5 \%$ agar and artificial seawater $(\mathrm{pH} 7.0)$ at $15{ }^{\circ} \mathrm{C}$ (Zhou et al., 2009). Strain $\mathrm{E} 407-8^{\mathrm{T}}$ was able to form clear hydrolytic zones on this medium. The artificial seawater was prepared with synthetic sea salts (Marine Life Reef Salt, QingDao, China) and contained the following approximate ion concentrations $\left(\mathrm{g} \mathrm{l}^{-1}\right): \mathrm{Na}^{+}, 9.1 ; \mathrm{K}^{+}, 0.35 ; \mathrm{Mg}^{2+}, 1.25$; $\mathrm{Ca}^{2+}, 0.43 ; \mathrm{Sr}^{2+}, 0.0095 ; \mathrm{Cl}^{-}, 17.1 ; \mathrm{SO}_{4}^{2-}, 2.4 ; \mathrm{Br}^{-}, 0.06 ; \mathrm{F}^{-}$, $0.001 ; \mathrm{HCO}_{3}^{-}, 0.145$. The isolated strain $\mathrm{E} 407-8^{\mathrm{T}}$ was routinely cultivated on a solid medium containing $0.5 \%$ tryptone (Oxoid), $0.1 \%$ yeast extract (Oxoid), $1.5 \%$ agar and artificial seawater (hereafter referred to as marine agar) or in a liquid medium containing $0.5 \%$ tryptone, $0.1 \%$ yeast extract and artificial seawater (hereafter referred to as marine broth) at $30{ }^{\circ} \mathrm{C}$ and stored at $-80{ }^{\circ} \mathrm{C}$ in marine broth supplemented with $20 \%$ glycerol.

Cell morphology was observed by transmission electron microscopy (JEM-100CX II) using cells grown in marine broth at 15 or $30{ }^{\circ} \mathrm{C}$ for $24 \mathrm{~h}$. The cells were stained with $1 \%$ phosphotungstic acid. Gram-staining was performed using Hucker's staining method (Murray et al., 1994). Growth at $10,15,20,25,30,35,37,40,42,45,48$ and $50{ }^{\circ} \mathrm{C}$ was measured in marine broth. Growth at $\mathrm{pH}$ 5.0-11.0 (at intervals of $0.5 \mathrm{pH}$ units) was determined in a medium containing $0.5 \%$ tryptone, $0.1 \%$ yeast extract and distilled water at $30{ }^{\circ} \mathrm{C}$. The $\mathrm{pH}$ of the medium was adjusted with $1 \mathrm{M} \mathrm{NaOH}$ or $\mathrm{HCl}$. The $\mathrm{NaCl}$ concentration range (0-9\%, $\mathrm{w} / \mathrm{v}$, in increments of $0.5 \%$ ) for growth was tested at $30{ }^{\circ} \mathrm{C}$ in the same medium used for $\mathrm{pH}$ tests with different $\mathrm{NaCl}$ concentrations. Anaerobic growth was checked in an anaerobic chamber (Forma 1029; Thermo Electron) in marine broth 2216 (Difco) at $28{ }^{\circ} \mathrm{C}$ for 15 days.

Catalase activity was assessed by bubble formation in $3 \%$ (v/v) $\mathrm{H}_{2} \mathrm{O}_{2}$ solution. Oxidase activity was determined with commercial oxidase test strips (Merck). DNase activity was detected on DNase test agar (Oxoid) prepared using artificial seawater. Hydrolysis of starch, casein and Tweens 40 and 80 was determined on marine agar at $30{ }^{\circ} \mathrm{C}$ according to standard methods (Smibert \& Krieg, 1994). The ability to utilize various carbohydrates including Dglucose, $\mathrm{N}$-acetyl-D-glucosamine, sucrose, maltose, citrate, xylose, mannose, trehalose, cellobiose, galactose, raffinose, $\mathrm{L}$-arabinose and lactose as sole carbon and energy sources for growth was determined in a basal medium containing $0.054 \% \quad \mathrm{NH}_{4} \mathrm{Cl}, 3 \% \mathrm{NaCl}, 0.3 \% \mathrm{MgCl}_{2} .6 \mathrm{H}_{2} \mathrm{O}, 0.2 \%$ $\mathrm{K}_{2} \mathrm{SO}_{4}, 0.02 \% \mathrm{~K}_{2} \mathrm{HPO}_{4}, 0.001 \% \mathrm{CaCl}_{2}, 0.0006 \% \mathrm{FeCl}_{3}$. $6 \mathrm{H}_{2} \mathrm{O}, 0.0005 \% \mathrm{Na}_{2} \mathrm{MoO}_{4} .7 \mathrm{H}_{2} \mathrm{O}, 0.0004 \% \mathrm{CuCl}_{2} .2 \mathrm{H}_{2} \mathrm{O}$, $0.6 \%$ Tris and distilled water supplemented with $1 \%$ carbohydrate as described by Shieh et al. (2004). Enzyme activities and other physiological and biochemical traits were determined by using API ZYM, API 20E and API 20NE strips (bioMérieux) according to the manufacturer's instructions. Cells for inoculation of API ZYM, API $20 \mathrm{E}$ and API 20NE strips were suspended in artificial seawater; the API ZYM strip was read after $24 \mathrm{~h}$ and the API 20E and API 20NE strips were read after $72 \mathrm{~h}$ incubation at $30{ }^{\circ} \mathrm{C}$. Antibiotic susceptibility tests were performed using the disc-diffusion method on marine agar and growth inhibition zones were observed after 3 days of incubation at $30{ }^{\circ} \mathrm{C}$. $R$. aquimaris JCM $14331^{\mathrm{T}}$ obtained from the Japan Collection of Microorganisms and R. pacifica DSM $17616^{\mathrm{T}}$ obtained from the Deutsche Sammlung von Mikroorganismen und Zellkulturen GmbH (DSMZ) were used as reference strains in all the above tests.

Genomic DNA of strain E407-8 ${ }^{\mathrm{T}}$ was extracted using a bacterial genomic DNA isolation kit (BioTeke). The 16S rRNA gene was amplified by PCR from genomic DNA with primers 27F and 1492R (Lane, 1991). PCR products were purified using the E.Z.N.A. gel extraction kit (Omega BioTek). Purified PCR products were ligated into pMD 18-T vector (TaKaRa) and sequenced at Biosune Inc. (Shanghai, China) using an automated DNA sequencer (Applied Biosystems model 3730). The obtained 16S rRNA gene sequence of strain E407-8 ${ }^{\mathrm{T}}$ was compared with those deposited in GenBank using the BLAST program (http:// blast.ncbi.nlm.nih.gov/Blast.cgi) and further aligned manually with sequences of related taxa retrieved from GenBank using the MEGA software version 4.0 (Tamura et al., 2007). Phylogenetic trees were constructed by the same software, using the neighbour-joining (Saitou \& Nei, 1987) and maximum-parsimony (Fitch, 1971) methods and using bootstrap analyses (1000 replications) (Felsenstein, 1985). Evolutionary distances for the neighbour-joining method were computed using the Jukes \& Cantor (1969) model. DNA-DNA hybridization experiments between strain E407-8 ${ }^{\mathrm{T}}$ and the two closely related type strains $R$. aquimaris JCM $14331^{\mathrm{T}}$ and $R$. pacifica DSM $17616^{\mathrm{T}}$ were conducted at the DSMZ by using the methods of De Ley et al. (1970) as modified by Huß et al. (1983).

The genomic DNA G + C content was determined using HPLC (Mesbah et al., 1989). Respiratory lipoquinone analyses were carried out by the Identification Service of the DSMZ and Dr B. J. Tindall. Cellular fatty acid analyses, from cells grown in marine broth at $30{ }^{\circ} \mathrm{C}$ for $24 \mathrm{~h}$, were performed according to the instructions of the Sherlock Microbial Identification System (MIDI) at the Institute of Microbiology and Epidemiology, Academy of Military Medical Sciences, Beijing, PR China.

Phylogenetic analysis based on the 16S rRNA gene sequence revealed that strain E407- $8^{\mathrm{T}}$ was affiliated with the genus Rheinheimera. The strain shared the highest $16 \mathrm{~S}$ rRNA gene sequence similarity with $R$. pacifica KMM $1406^{\mathrm{T}}(97.5 \%)$ and $R$. aquimaris SW- $353^{\mathrm{T}}(97.4 \%)$ and 94.7-96.7\% similarity with type strains of other recognized Rheinheimera species. The neighbour-joining phylogenetic tree showed that strain E407- $8^{\mathrm{T}}$ clustered with members of the genus Rheinheimera and formed an intragenus branch with $R$. pacifica KMM $1406^{\mathrm{T}}$ with $80 \%$ bootstrap support (Fig. 1). The maximum-parsimony phylogenetic tree showed a similar topology (Supplementary Fig. S1, 


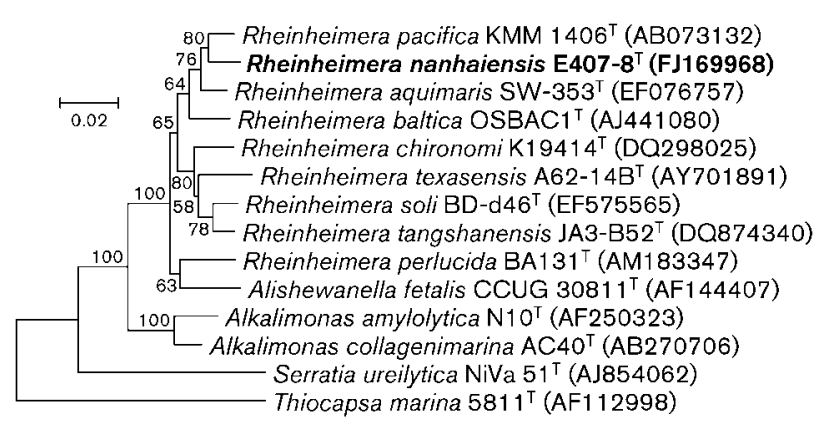

Fig. 1. Neighbour-joining phylogenetic tree based on 16S rRNA gene sequences showing the phylogenetic positions of strain E407-8 ${ }^{\top}$, members of other Rheinheimera species and representatives of some other related genera. Bootstrap percentages (from 1000 replicates) are indicated at nodes. Bar, 0.02 substitutions per nucleotide position.

available in IJSEM Online). DNA-DNA relatedness between strain E407- $8^{\mathrm{T}}$ and $R$. pacifica DSM $17616^{\mathrm{T}}$ and R. aquimaris $\mathrm{JCM} 14331^{\mathrm{T}}$ was $25.2 \%(25.3 \%$ in the duplicate measurement) and $9.4 \%(6.5 \%)$, respectively. Since strains sharing less than $70 \%$ DNA-DNA relatedness or less than $97 \%$ 16S rRNA gene sequence similarity are generally considered to belong to separate species (Wayne et al., 1987; Stackebrandt \& Goebel, 1994; Stackebrandt et al., 2002), the above genotypic data indicated that strain E407- $8^{\mathrm{T}}$ represents a novel species in the genus Rheinheimera.

The DNA G + C content of strain $\mathrm{E} 407-8^{\mathrm{T}}$ was $51.0 \mathrm{~mol} \%$, which was close to the highest $\mathrm{G}+\mathrm{C}$ content reported for Rheinheimera species (50.5 mol\%; Yoon et al., 2007). The major fatty acids $(>5 \%)$ of strain E407- $8^{\mathrm{T}}$ were summed feature $3\left(\mathrm{C}_{16: 1} \omega 7 c\right.$ and/or iso- $\left.\mathrm{C}_{15: 0} \quad 2-\mathrm{OH} ; 21.1 \%\right)$, $\mathrm{C}_{17: 1} \omega 8 c(14.5 \%), \mathrm{C}_{16: 0}(11.9 \%), \mathrm{C}_{18: 1} \omega 7 c(10.0 \%)$ and $\mathrm{C}_{17: 0}(8.6 \%)$. The fatty acid profile of strain $\mathrm{E} 407-8^{\mathrm{T}}$ was generally similar to those of other known Rheinheimera species, which are characterized by unsaturated fatty acids including $\mathrm{C}_{16: 1} \omega 7 c, \mathrm{C}_{17: 1} \omega 8 c$ and $\mathrm{C}_{18: 1} \omega 7 c$ and the straight-chain fatty acid $\mathrm{C}_{16: 0}$ as major fatty acid components (Table 1). The dominant respiratory quinone of strain E407-8 ${ }^{\mathrm{T}}$ was ubiquinone Q-8 (98\%); minor amounts of Q-7 (2\%) was also detected.

Cells of strain E407- $8^{\mathrm{T}}$ were found to be able to produce prosthecae (Fig. 2), a cellular substructure formed by cytoplasmic extrusion from the cell wall and considered to help bacteria to improve nutrient uptake efficiency by

Table 1. Fatty acid compositions of strain $E 407-8^{\top}$ and type strains of other Rheinheimera species

Strains: 1, E407-8 ${ }^{\mathrm{T}} ; 2$, R. pacifica DSM $17616^{\mathrm{T}} ; 3$, R. aquimaris JCM $14331^{\mathrm{T}} ; 4$, R. soli BD-d46 ${ }^{\mathrm{T}}$ (data from Ryu et al., 2008); 5 , R. chironomi K19414 ${ }^{\mathrm{T}}$ (Halpern et al., 2007); 6, R. tangshanensis JA3-B52 ${ }^{\mathrm{T}}$ (Zhang et al., 2008); 7, R. baltica OSBAC1 ${ }^{\mathrm{T}}$ (Brettar et al., 2002); 8, R. texasensis A62-14B ${ }^{\mathrm{T}}$ (Merchant et al., 2007); 9, R. perlucida BA131 $1^{\mathrm{T}}$ (Brettar et al., 2006). Values are percentages of total fatty acids; -, not detected or not reported.

\begin{tabular}{|c|c|c|c|c|c|c|c|c|c|c|c|}
\hline \multirow[t]{2}{*}{ Fatty acid } & \multirow[t]{2}{*}{1} & \multicolumn{2}{|c|}{2} & \multicolumn{2}{|c|}{3} & \multirow[t]{2}{*}{4} & \multirow[t]{2}{*}{5} & \multirow[t]{2}{*}{6} & \multirow[t]{2}{*}{7} & \multirow[t]{2}{*}{8} & \multirow[t]{2}{*}{9} \\
\hline & & This study & $\begin{array}{l}\text { Romanenko } \\
\text { et al. (2003) }\end{array}$ & $\begin{array}{l}\text { This } \\
\text { study }\end{array}$ & $\begin{array}{l}\text { Yoon et al. } \\
\quad(2007)\end{array}$ & & & & & & \\
\hline $\mathrm{C}_{10: 0}$ & 0.2 & 0.1 & - & 0.1 & - & 3.7 & 1.2 & 2.2 & - & - & - \\
\hline $\mathrm{C}_{11: 0} 3-\mathrm{OH}$ & 2.1 & 0.4 & - & 1.5 & 1.7 & 4.6 & 5.5 & 3.3 & - & - & 1.2 \\
\hline $\mathrm{C}_{12: 0}$ & 1.3 & 2.8 & - & 2.1 & 3.1 & 0.5 & 1.1 & - & 1.4 & 2.0 & 1.1 \\
\hline $\mathrm{C}_{12: 0} 3-\mathrm{OH}$ & 3.9 & 4.7 & - & 3.6 & 5.6 & 9.5 & 8.5 & 7.2 & 5.3 & 12.8 & 3.1 \\
\hline $\mathrm{C}_{13: 0} 3-\mathrm{OH}$ & $2.7^{a_{\star}}$ & $1.0^{a}$ & - & $2.1^{a}$ & $3.0^{a}$ & $1.3^{a}$ & $1.9^{a}$ & - & 1.0 & - & 0.7 \\
\hline $\mathrm{C}_{14: 0}$ & 0.7 & 1.4 & - & 0.9 & 2.1 & 1.4 & 0.9 & - & 2.3 & - & 1.8 \\
\hline $\mathrm{C}_{14: 0} 3-\mathrm{OH}$ & $2.0^{b}$ & $3.8^{b}$ & - & $2.1^{b}$ & $3.4^{b}$ & $0.3^{b}$ & $0.3^{b}$ & - & 1.6 & - & 0.5 \\
\hline $\mathrm{C}_{15: 0}$ & 2.8 & 1.0 & 2.4 & 3.2 & 2.7 & 6.0 & 6.9 & 2.1 & 1.7 & - & 3.0 \\
\hline $\mathrm{C}_{15: 1} \omega 8 c$ & 4.5 & 1.3 & 3.3 & 3.8 & 1.4 & 2.9 & 2.8 & 3.0 & 1.7 & - & 2.0 \\
\hline$C_{16: 0}$ & 11.9 & 19.9 & 19.1 & 17.7 & 25.1 & 10.8 & 14.8 & 7.8 & 19.5 & 19.0 & 17.1 \\
\hline iso- $\mathrm{C}_{16: 0}$ & 3.7 & 1.5 & 3.7 & 2.1 & 0.7 & 0.8 & 1.5 & - & 0.5 & - & 1.2 \\
\hline $\mathrm{C}_{16: 1} \omega 7 c$ & $21.1^{c}$ & $28.5^{c}$ & - & $23.4^{c}$ & $13.8^{c}$ & $24.0^{c}$ & $25.8^{c}$ & 33.7 & 33.6 & 38.6 & 33.4 \\
\hline $\mathrm{C}_{16: 1} \omega 9 c$ & 0.6 & 2.1 & 25.5 & 2.1 & 2.3 & 0.7 & - & - & 1.7 & - & - \\
\hline $\mathrm{C}_{17: 0}$ & 8.6 & 4.1 & 8.1 & 8.1 & 9.3 & 4.2 & 5.8 & - & 3.3 & - & 3.4 \\
\hline $\mathrm{C}_{17: 1} \omega 8 c$ & 14.5 & 5.6 & 11.7 & 11.6 & 9.7 & 12.5 & 7.6 & 15.2 & 5.7 & 3.8 & 13.9 \\
\hline $\mathrm{C}_{18: 0}$ & 0.6 & 1.5 & - & 0.8 & 1.5 & 0.4 & 0.3 & - & 0.5 & 2.0 & 0.4 \\
\hline iso- $\mathrm{C}_{18: 0}$ & 1.2 & 0.6 & 1.3 & 0.6 & - & - & - & - & - & - & - \\
\hline $\mathrm{C}_{18: 1} \omega 7 c$ & 10.0 & 15.9 & 15.7 & 8.1 & 11.0 & 7.1 & 6.7 & 13.4 & 15.9 & 7.7 & 12.4 \\
\hline
\end{tabular}

${ }^{*}$ Reported as: $a$, summed feature $1\left(\mathrm{C}_{13: 0} 3-\mathrm{OH}\right.$ and/or iso- $\left.\mathrm{C}_{15: 1} \mathrm{H}\right) ; b$, summed feature $2\left(\mathrm{C}_{14: 0} 3-\mathrm{OH}\right.$ and/or iso- $\left.\mathrm{C}_{16: 1} \mathrm{I}\right)$; $c$, summed feature 3 $\left(\mathrm{C}_{16: 1} \omega 7 \mathrm{c}\right.$ and/or iso- $\left.\mathrm{C}_{15: 0} 2-\mathrm{OH}\right)$. Summed features are groups of two or three fatty acids that cannot be separated by GLC with the MIDI System. 
(a)

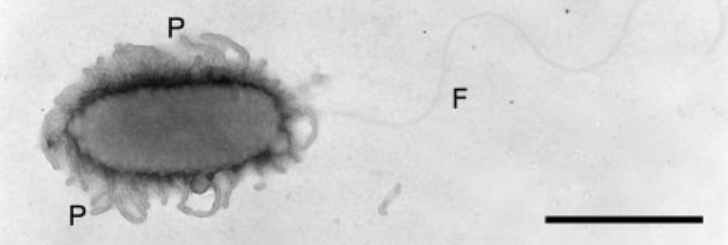

(b)

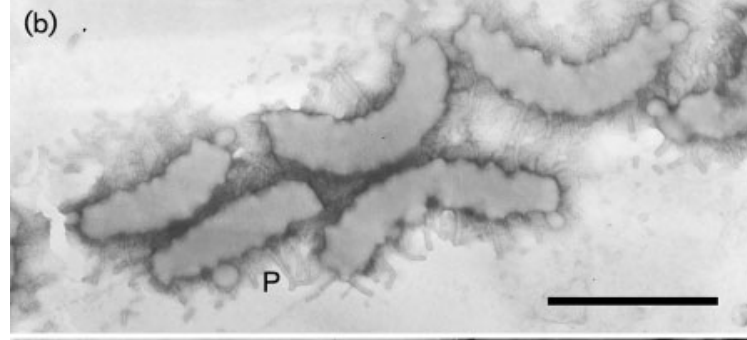

(c)

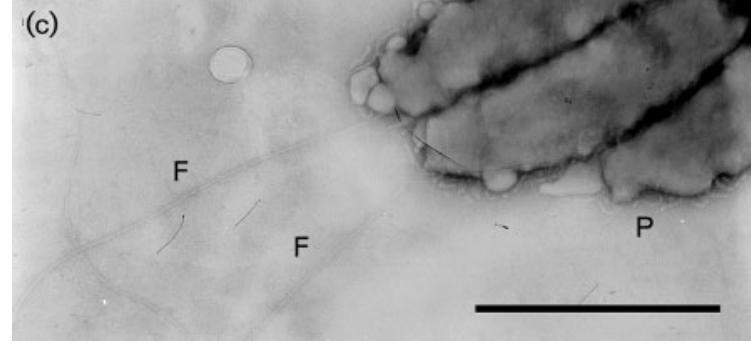

Fig. 2. Transmission electron micrographs of negatively stained cells of strain E407-8 ${ }^{\top}$, showing a single polar flagellum $(F)$ and prosthecae $(P)$. Cells observed were cultivated in marine broth at $15^{\circ} \mathrm{C}(\mathrm{a}, \mathrm{b})$ and $30{ }^{\circ} \mathrm{C}$ (c) for $24 \mathrm{~h}$. Bars, $1 \mu \mathrm{m}$.

increasing the cellular surface-to-volume ratio (Hedlund et al., 1997; Van Trappen et al., 2004a; Young, 2006). To the best of our knowledge, this is the first observation of prostheca formation in the genus Rheinheimera; members of the class Gammaproteobacteria able to produce prosthecae have been reported from the genera Alteromonas (Van Trappen et al., 2004a; Chiu et al., 2007; Vandecandelaere et al., 2008), Glaciecola (Van Trappen et al., 2004b; Chen et al., 2009), Pseudidiomarina (Jean et al., 2006) and Simiduia (Shieh et al., 2008).

Other morphological, physiological and biochemical characteristics of strain $\mathrm{E} 407-8^{\mathrm{T}}$ are given in the species description and in Table 2. Cells of strain E407- $8^{\mathrm{T}}$ were Gram-negative, oxidase- and catalase-positive, flagellated rods (Fig. 2). Consistent with other known Rheinheimera species, the strain could grow across broad ranges of temperature $\left(10-48{ }^{\circ} \mathrm{C}\right)$ and $\mathrm{NaCl}$ concentration $(0-8 \%)$ and could assimilate $\mathrm{N}$-acetylglucosamine and hydrolyse gelatin, starch and aesculin. The above phenotypic features supported the assignment of the strain to the genus Rheinheimera. There was also a range of phenotypic characteristics that could be used to differentiate strain E407- $8^{\mathrm{T}}$ from recognized Rheinheimera species, such as flagellum position and number, prostheca formation, reduction of nitrate, oxygen requirement, ranges of salt, temperature and $\mathrm{pH}$ for growth, enzyme activities, carbohydrate assimilation and DNA $\mathrm{G}+\mathrm{C}$ content (Table 2).

Taken together, the results of phylogenetic analysis of $16 \mathrm{~S}$ rRNA gene sequences, DNA-DNA hybridization experiments and analysis of fatty acid profiles and phenotypic characteristics indicate that strain $\mathrm{E} 407-8^{\mathrm{T}}$ should be assigned to the genus Rheinheimera and represents a novel species of the genus, for which the name Rheinheimera nanhaiensis sp. nov. is proposed.

Some properties of strain $\mathrm{E} 407-8^{\mathrm{T}}$ are not in agreement with or were not included in the original and emended descriptions of the genus Rheinheimera (Brettar et al., 2002; Merchant et al., 2007), such as facultatively aerobic growth, the ability to produce prosthecae, growth at $48{ }^{\circ} \mathrm{C}$ or in $8 \% \mathrm{NaCl}$ and the presence of summed feature 3 among the major fatty acids. Similar discrepancies can also be observed for some other Rheinheimera species with validly published names, indicating the necessity to emend further the description of the genus, as follows.

\section{Emended description of the genus Rheinheimera Brettar et al. 2002 emend. Merchant et al. 2007}

The description is as given by Brettar et al. (2002) and Merchant et al. (2007) with the following amendments. Cells of some species can produce prosthecae. Growth is aerobic or facultatively aerobic, chemoheterotrophic and occurs at $4-48{ }^{\circ} \mathrm{C}$. Dominant fatty acids are $\mathrm{C}_{16: 1} \omega 7 c$ or summed feature $3\left(\mathrm{C}_{16: 1} \omega 7 c\right.$ and/or iso- $\left.\mathrm{C}_{15: 0} 2-\mathrm{OH}\right)$, $\mathrm{C}_{16: 0}, \mathrm{C}_{17: 1} \omega 8 c$ and $\mathrm{C}_{18: 1} \omega 7 c$ (Table 1). Strains do not necessarily need $\mathrm{NaCl}$ for growth and cannot tolerate $>8 \%$ $\mathrm{NaCl}$.

\section{Description of Rheinheimera nanhaiensis sp. nov.}

Rheinheimera nanhaiensis (nan.hai.en'sis. N.L. fem. adj. nanhaiensis pertaining to NanHai, the Chinese name for the South China Sea, where the type strain was isolated).

Cells are Gram-negative, straight or curved rods (1.0$2.0 \mu \mathrm{m}$ long and $0.3-0.5 \mu \mathrm{m}$ wide). Motile by a single polar flagellum. Able to form prosthecae. Facultatively aerobic. Colonies on marine agar are slightly yellow, circular (1.5$2.0 \mathrm{~mm}$ in diameter) and convex with smooth surfaces after incubation for $48 \mathrm{~h}$ at $30{ }^{\circ} \mathrm{C}$. Oxidase- and catalasepositive. Reduces nitrate to nitrite. Grows at $10-48{ }^{\circ} \mathrm{C}$ (optimum, $37{ }^{\circ} \mathrm{C}$ ), but not at $50{ }^{\circ} \mathrm{C}$. Grows in $0-8 \%(\mathrm{w} / \mathrm{v})$ $\mathrm{NaCl}$ (optimum, 0.5-2.5\%) and at pH 5.5-10.0 (optimum, $\mathrm{pH}$ 7.5-8.5). Hydrolyses starch, gelatin, casein, DNA and Tweens 40 and 80 . Able to utilize D-glucose, $\mathrm{N}$-acetylD-glucosamine, sucrose, trehalose, cellobiose and maltose as sole carbon and energy sources. In API 20NE tests, positive for reduction of nitrate to nitrite, gelatinase, assimilation of D-glucose, $\mathrm{N}$-acetylglucosamine and maltose and hydrolysis of aesculin and negative for indole production, arginine dihydrolase, urease, $\beta$-galactosidase, 
Table 2. Differential characteristics of strain $\mathrm{E} 407-8^{\top}$ and type strains of other Rheinheimera species

Strains: 1, E407-8 ${ }^{\mathrm{T}}$; 2, R. pacifica DSM $17616^{\mathrm{T}}$ (unless indicated, data from Romanenko et al., 2003); 3, R. aquimaris JCM 14331 ${ }^{\mathrm{T}}$ (Yoon et al., 2007); 4, R. soli BD-d46 ${ }^{\mathrm{T}}$ (Ryu et al., 2008); 5, R. chironomi K19414 ${ }^{\mathrm{T}}$ (Halpern et al., 2007); 6, R. tangshanensis JA3-B52 ${ }^{\mathrm{T}}$ (Zhang et al., 2008); 7, $R$.

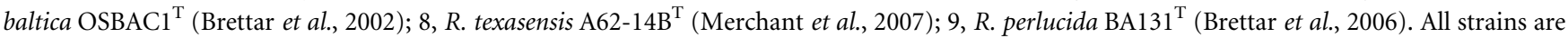
Gram-negative and positive for oxidase, assimilation of $\mathrm{N}$-acetylglucosamine and hydrolysis of gelatin, starch and aesculin. + , Positive; w, weakly positive; -, negative; ND, not detected or no data available.

\begin{tabular}{|c|c|c|c|c|c|c|c|c|c|}
\hline Characteristic & 1 & 2 & 3 & 4 & 5 & 6 & 7 & 8 & 9 \\
\hline \multicolumn{10}{|l|}{ Cell size $(\mu \mathrm{m})$} \\
\hline Length & $1.0-2.0$ & $1.8-2.0$ & $0.3-5.0$ & $2.0-3.5$ & $1.0-2.4$ & $1.3-2.5$ & $0.9-2.5$ & $1.2-2.5$ & $0.9-2.4$ \\
\hline Flagella $\dagger$ & S, P & $\mathrm{M}, \mathrm{P}$ and $\mathrm{L}$ & S, P & S, P & S, P & $\mathrm{S}, \mathrm{P}$ or $\mathrm{L}$ & S, P & $\mathrm{S}, \mathrm{P}$ or $\mathrm{M}, \mathrm{P}$ and $\mathrm{L}$ & S, P \\
\hline Oxygen requirement $\ddagger$ & $\mathrm{FA}$ & A & A & $\mathrm{FA}$ & $\mathrm{FA}$ & A & A & $\mathrm{FA}$ & $\mathrm{FA}$ \\
\hline \multicolumn{10}{|l|}{ Temperature for growth $\left({ }^{\circ} \mathrm{C}\right)$} \\
\hline Range & $10-48$ & $4-37$ & $4-43$ & $15-35$ & $4-40$ & $10-37$ & $4-30$ & $25-37$ & $4-37$ \\
\hline Optimum & 37 & $25-30 \$$ & $30-37$ & $25-30$ & $30-37$ & 30 & $20-25$ & $30-37$ & $20-30$ \\
\hline \multicolumn{10}{|l|}{$\begin{array}{l}\mathrm{NaCl} \text { concentration for growth } \\
(\%, w / v)\end{array}$} \\
\hline Optimum & $7.5-8.5$ & $8.0-8.5 \S$ & $7.0-8.0$ & $7.0-7.5$ & $7.5-8.0$ & 7.0 & 7.0 & $7.5-8.0$ & 7.0 \\
\hline \multicolumn{10}{|l|}{ API ZYM results } \\
\hline$N$-Acetylglucosaminidase & + & $+\S$ & $-\S$ & + & + & ND & - & $\mathrm{ND}$ & + \\
\hline$\alpha$-Chymotrypsin & + & $+\S$ & $-\S$ & + & + & $\mathrm{ND}$ & - & $\mathrm{ND}$ & + \\
\hline Acid phosphatase & + & $+\S$ & $+\S$ & $\mathrm{W}$ & + & $\mathrm{ND}$ & - & ND & + \\
\hline Esterase (C4) & + & $-\S$ & $+\S$ & + & + & $\mathrm{ND}$ & - & ND & + \\
\hline$\beta$-Glucosidase & - & $-\S$ & $-\S$ & - & - & $\mathrm{ND}$ & + & $\mathrm{ND}$ & + \\
\hline \multicolumn{10}{|l|}{ Assimilation of: } \\
\hline D-Glucose & + & $+\S$ & $+\S$ & + & + & + & + & + & - \\
\hline L-Arabinose & - & $+\S$ & $-\S$ & + & - & + & - & + & - \\
\hline Maltose & + & $+\S$ & $+\S$ & + & + & - & + & - & - \\
\hline
\end{tabular}

${ }^{\star} \mathrm{C}$, Cocci; $\mathrm{CR}$, curved rods; $\mathrm{R}$, rods; SR, straight rods.

$\dagger \mathrm{M}$, Multiple; $\mathrm{s}$, single; L, lateral; $\mathrm{P}$, polar.

$\ddagger A$, Aerobic; FA, facultatively aerobic.

$\$$ Result from this study.

acid production from glucose and assimilation of arabinose, mannose, mannitol, gluconate, caprate, adipate, malate, citrate and phenylacetate. In API 20E tests, positive for gelatinase, weakly positive for acid production from sucrose and negative for $\beta$-galactosidase, arginine dihydrolase, lysine decarboxylase, ornithine decarboxylase, utilization of citrate, $\mathrm{H}_{2} \mathrm{~S}$ production, urease, tryptophan deaminase, indole production, the Voges-Proskauer test and acid production from glucose, mannitol, inositol, sorbitol, rhamnose, melibiose, amygdalin and arabinose. With API ZYM strips, the following enzyme activities are detected: $N$-acetyl- $\beta$-glucosaminidase, $\alpha$-chymotrypsin, trypsin, alkaline and acid phosphatases, esterase (C4), esterase lipase (C8), leucine arylamidase, valine arylamidase and naphthol-AS-BI-phosphohydrolase; activities of $\alpha$ - and $\beta$-galactosidase, $\beta$-glucuronidase, $\alpha$ - and $\beta$-glucosidase, $\alpha$-mannosidase, $\beta$-fucosidase, lipase (C14) and cystine arylamidase are not detected. Susceptible to ( $\mu \mathrm{g}$ per disc) chloramphenicol (30), erythromycin (15), gentamicin (10), kanamycin (30) and streptomycin (10), but resistant to ampicillin (10), penicillin G (10), vancomycin (30), lincomycin (2) and tetracycline (30). The respiratory 
lipoquinones are Q-8 $(98 \%)$ and Q-7 (2\%). The major fatty acids $(>5 \%)$ are summed feature $3\left(\mathrm{C}_{16: 1} \omega 7 \mathrm{c}\right.$ and/or iso- $\left.\mathrm{C}_{15: 0} 2-\mathrm{OH}\right), \mathrm{C}_{17: 1} \omega 8 c, \mathrm{C}_{16: 0}, \mathrm{C}_{18: 1} \omega 7 c$ and $\mathrm{C}_{17: 0}$. The DNA $\mathrm{G}+\mathrm{C}$ content of the type strain is $51.0 \mathrm{~mol} \%$.

The type strain is E407-8 ${ }^{\mathrm{T}}$ (=CCTCC AB $209089^{\mathrm{T}}=$ KACC $14030^{\mathrm{T}}$ ), isolated from marine sediments of the South China Sea.

\section{Acknowledgements}

The work was supported financially by the Hi-Tech Research and Development Program of China (2007AA091903, 2007AA021306), the National Natural Science Foundation of China (30770040, 30770062) and the COMRA Program (DYXM-115-02-2-6).

\section{References}

Brettar, I., Christen, R. \& Höfle, M. G. (2002). Rheinheimera baltica gen. nov., sp. nov., a blue-coloured bacterium isolated from the central Baltic Sea. Int J Syst Evol Microbiol 52, 1851-1857.

Brettar, I., Christen, R. \& Höfle, M. G. (2006). Rheinheimera perlucida sp. nov., a marine bacterium of the Gammaproteobacteria isolated from surface water of the central Baltic Sea. Int J Syst Evol Microbiol 56, 2177-2183.

Chen, L. P., Xu, H. Y., Fu, S. Z., Fan, H. X., Liu, Y. H., Liu, S. J. \& Liu, Z. P. (2009). Glaciecola lipolytica sp. nov., isolated from seawater near Tianjin city, China. Int J Syst Evol Microbiol 59, 73-76.

Chiu, H. H., Shieh, W. Y., Lin, S. Y., Tseng, C. M., Chiang, P. W. \& Wagner-Döbler, I. (2007). Alteromonas tagae sp. nov. and Alteromonas simiduii sp. nov., mercury-resistant bacteria isolated from a Taiwanese estuary. Int J Syst Evol Microbiol 57, 1209-1216.

De Ley, J., Cattoir, H. \& Reynaerts, A. (1970). The quantitative measurement of DNA hybridization from renaturation rates. Eur $J$ Biochem 12, 133-142.

Felsenstein, J. (1985). Confidence limits on phylogenies: an approach using the bootstrap. Evolution 39, 783-791.

Fitch, W. M. (1971). Toward defining the course of evolution: minimum change for a specific tree topology. Syst Zool 20, 406-416.

Halpern, M., Senderovich, Y. \& Snir, S. (2007). Rheinheimera chironomi sp. nov., isolated from a chironomid (Diptera; Chironomidae) egg mass. Int J Syst Evol Microbiol 57, 1872-1875.

Hedlund, B. P., Gosink, J. J. \& Staley, J. T. (1997). Verrucomicrobia div. nov., a new division of the bacteria containing three new species of Prosthecobacter. Antonie van Leeuwenhoek 72, 29-38.

Huß, V. A. R., Festl, H. \& Schleifer, K. H. (1983). Studies on the spectrophotometric determination of DNA hybridization from renaturation rates. Syst Appl Microbiol 4, 184-192.

Jean, W. D., Shieh, W. Y. \& Chiu, H. H. (2006). Pseudidiomarina taiwanensis gen. nov., sp. nov., a marine bacterium isolated from shallow coastal water of An-Ping Harbour, Taiwan, and emended description of the family Idiomarinaceae. Int J Syst Evol Microbiol 56, 899-905.

Jukes, T. H. \& Cantor, C. R. (1969). Evolution of protein molecules. In Mammalian Protein Metabolism, vol. 3, pp. 21-132. Edited by H. N. Munro. New York: Academic Press.

Lane, D. J. (1991). 16S/23S rRNA sequencing. In Nucleic Acid Techniques in Bacterial Systematics, pp. 115-175. Edited by E. Stackebrandt \& M. Goodfellow. Chichester: Wiley.
Merchant, M. M., Welsh, A. K. \& McLean, R. J. C. (2007). Rheinheimera texasensis sp. nov., a halointolerant freshwater oligotroph. Int J Syst Evol Microbiol 57, 2376-2380.

Mesbah, M., Premachandran, U. \& Whitman, W. B. (1989). Precise measurement of the $\mathrm{G}+\mathrm{C}$ content of deoxyribonucleic acid by highperformance liquid chromatography. Int J Syst Bacteriol 39, 159-167.

Murray, R. G. E., Doetsch, R. N. \& Robinow, C. F. (1994). Determinative and cytological light microscopy. In Methods for General and Molecular Bacteriology, pp. 21-41. Edited by P. Gerhardt, R. G. E. Murray, W. A. Wood \& N. R. Krieg. Washington, DC: American Society for Microbiology.

Romanenko, L. A., Uchino, M., Falsen, E., Zhukova, N. V., Mikhailov, V. V. \& Uchimura, T. (2003). Rheinheimera pacifica sp. nov., a novel halotolerant bacterium isolated from deep sea water of the Pacific. Int J Syst Evol Microbiol 53, 1973-1977.

Ryu, S. H., Chung, B. S., Park, M., Lee, S. S., Lee, S. S. \& Jeon, C. O. (2008). Rheinheimera soli sp. nov., a gammaproteobacterium isolated from soil in Korea. Int J Syst Evol Microbiol 58, 2271-2274.

Saitou, N. \& Nei, M. (1987). The neighbor-joining method: a new method for reconstructing phylogenetic trees. Mol Biol Evol 4, 406425.

Shieh, W. Y., Lin, Y. T. \& Jean, W. D. (2004). Pseudovibrio denitrificans gen. nov., sp. nov., a marine, facultatively anaerobic, fermentative bacterium capable of denitrification. Int J Syst Evol Microbiol 54, 2307-2312.

Shieh, W. Y., Liu, T. Y., Lin, S. Y., Jean, W. D. \& Chen, J. S. (2008). Simiduia agarivorans gen. nov., sp. nov., a marine, agarolytic bacterium isolated from shallow coastal water from Keelung, Taiwan. Int J Syst Evol Microbiol 58, 895-900.

Smibert, R. M. \& Krieg, N. R. (1994). Phenotypic characterization. In Methods for General and Molecular Bacteriology, pp. 607-654. Edited by P. Gerhardt, R. G. E. Murray, W. A. Wood \& N. R. Krieg. Washington, DC: American Society for Microbiology.

Stackebrandt, E. \& Goebel, B. M. (1994). Taxonomic note: a place for DNA-DNA reassociation and 16S rRNA sequence analysis in the present species definition in bacteriology. Int J Syst Bacteriol 44, 846849.

Stackebrandt, E., Frederiksen, W., Garrity, G. M., Grimont, P. A. D., Kämpfer, P., Maiden, M. C. J., Nesme, X., Rosselló-Mora, R., Swings, J. $\&$ other authors (2002). Report of the ad hoc committee for the reevaluation of the species definition in bacteriology. Int J Syst Evol Microbiol 52, 1043-1047.

Tamura, K., Dudley, J., Nei, M. \& Kumar, S. (2007). MEGA4: molecular evolutionary genetics analysis (MEGA) software version 4.0. Mol Biol Evol 24, 1596-1599.

Van Trappen, S., Tan, T. L., Yang, J., Mergaert, J. \& Swings, J. (2004a). Alteromonas stellipolaris sp. nov., a novel, budding, prosthecate bacterium from Antarctic seas, and emended description of the genus Alteromonas. Int J Syst Evol Microbiol 54, 1157-1163.

Van Trappen, S., Tan, T. L., Yang, J., Mergaert, J. \& Swings, J. (2004b). Glaciecola polaris sp. nov., a novel budding and prosthecate bacterium from the Arctic Ocean, and emended description of the genus Glaciecola. Int J Syst Evol Microbiol 54, 1765-1771.

Vandecandelaere, I., Nercessian, O., Segaert, E., Achouak, W., Mollica, A., Faimali, M., De Vos, P. \& Vandamme, P. (2008). Alteromonas genovensis sp. nov., isolated from a marine electroactive biofilm and emended description of Alteromonas macleodii Baumann et al. 1972 (Approved Lists 1980). Int J Syst Evol Microbiol 58, 25892596.

Wayne, L. G., Brenner, D. J., Colwell, R. R., Grimont, P. A. D., Kandler, O., Krichevsky, M. I., Moore, L. H., Moore, W. E. C., Murray, R. G. E. \& other authors (1987). Report of the ad hoc committee on the reconciliation 
of approaches to bacterial systematics. Int J Syst Bacteriol 37, 463464.

Yoon, J.-H., Bae, S. E., Kang, S.-J. \& Oh, T.-K. (2007). Rheinheimera aquimaris sp. nov., isolated from seawater of the East Sea in Korea. Int J Syst Evol Microbiol 57, 1386-1390.

Young, K. D. (2006). The selective value of bacterial shape. Microbiol Mol Biol Rev 70, 660-703.
Zhang, X. X., Sun, L., Qiu, F. B., McLean, R. J. C., Jiang, R. B. \& Song, W. (2008). Rheinheimera tangshanensis sp. nov., a rice root-associated bacterium. Int J Syst Evol Microbiol 58, 2420-2424.

Zhou, M. Y., Chen, X. L., Zhao, H. L., Dang, H. Y., Luan, X. W., Zhang, X. Y., He, H. L., Zhou, B. C. \& Zhang, Y. Z. (2009). Diversity of both the cultivable protease-producing bacteria and their extracellular proteases in the sediments of the South China sea. Microb Ecol 58, $582-590$. 